\title{
On the Use of L1 in English Language Classes in Light of Vygotsky's Genotypic Approach: A Case of Persian Language
}

Majid Elahi Shirvan

Assistant Professor, University of Bojnord, Iran; Elahimajid64@gmail.com

Samira Rahmani

M. A. Imam Reza International University, Iran; Rahmani.samira92@gmail.com

Laleh Sorayyaee

M.A. Imam Reza International University, Iran; Laleh_sorayyaee@yahoo.com

Mehran Baradaran Kashi

B.A. Imam Reza International University, Iran; baradaranmehran91@gmail.com

Doi:10.5901/mjss.2015.v6n6s2p210

\section{Abstract}

One main challenge occupying the mind of almost every English language teacher in Iran is the use of Persian in their classroom. They might be warned not to use Persian in their classes, especially with children, while they might be encouraged by several theories to use Persian for many reasons in their training courses. Besides, children's parents might expect teachers not to use Persian in the class. The dilemma might still exist and this can be explored in light of the genesis underpinning teachers', learners', and parents' thoughts and attitudes regarding the use of Persian in the class. Thus, the purpose of the present study was to explore Iranian English language teachers', learners', and parents' attitudes towards the use of Farsi in the classroom. To do so, unstructured interviews were conducted with 30 English language teachers and 40 English language learners and their parents within a period of six month. Moreover, case studies of the challenges on the use of Persian over English language assignments between parents and their children were video recorded. The findings of this study indicate that the controversies over the use of Persian in Iranian classrooms can be explained via Vygotsky's genotypic approach where the microgeny of learning English language is under the influence of the contrast between the ontogenetic developments of English language teachers and the social, historical, and cultural span developed by the policies of the institutes.

Keywords: Use of Farsi, Genotypic approach, Ontogeny, Microgeny, Social-historical span

\section{Introduction}

The use of mother tongue in the second language learning classes has been a controversial issue in the field of applied linguistics. There have always been contradicting views about whether to use learners' mother tongue in learning the second language or not. The literature related to this controversial issue is occupied with theories and approaches in favor of and against using L1 in L2 instruction. Some approaches like the behavioristic ones maintained that the target language must be the only way of conveying the information to second language learners, and the use of L1 should be banned at all costs in order to improve the effectiveness of the instruction in EFL classes. It was a common belief that using L1 in L2 classes is one of the obstacles that prevents the appropriate second language learning and causes some serious problems in learners' L2 learning process. Thus, there was a consensus among the teachers following these approaches that the transferred knowledge of $L 1$ into $L 2$ classes had an interfering effect on $L 2$ learning because the source of all the errors and mistakes learners made in the class was rooted in the use of L1.

On the other hand, some other cognitive and sociocultural approaches regarded using $L 1$ as an intervening tool in presenting $\mathrm{L} 2$ items and asserted that the judicious and reasonable use of $\mathrm{L} 1$ can pave the way for more successful language learning. Thus, the use of $L 1$ could contribute to the creativity required for receiving feedback to develop the interlanguage or it could be used as a mediator for more explanation and clarification at some specific time and situations 
in case students were confused and needed to improve their potential learning. For this reason, in recent years, there have been significant shifts towards using L1 in L2 classes and many of the teachers and researchers have reached to the conclusion that there should be a judicious and balanced use of learners' mother tongue in learning the second language(Cook, 2001a; Turnbull, 2001). However, when applied within the context of the institutes, some challenges might arise due to the contradictory viewpoints between teachers and the policies and regularities of the institutes. Despite the emergence of theories advocating the use of L1 in the classrooms since a decade ago, the controversy over the use of the first language in the classroom still seems a heated debate within the context of Iran. English language teachers report that what they have studied regarding the benefits of the use of L1 seems not very practical and feasible in their classes at the institutes because they are still banned from using Persian language. Thus, an ecological exploration of the use of Persian language in terms of teachers', learners', and parents' attitudes seems useful to shed more lights on this controversy in the Iranian context.

\section{Review of Literature}

It is clear that humans are social creatures and history shows their willingness to communicate in different ways, for example by drawing pictures on the rock which was done by cavemen. By the time they developed their communication through language they took advantage of their first language (L1), or mother tongue. Mother tongue is used for the language that children learn at their homes and usually they acquire it as a means of communication from their parents (Basavadatta \& Amit, 2011). However, when they started leaning another language, second or foreign, the controversy over the use of this mother tongue started too. The literature on the controversy over the use of L1 in the second or foreign language classes can be discussed from several interconnected perspectives such as psychological, methodological and sociological, to name but a few.

Traditionally, teaching foreign languages was based on the student's own first language practiced in some approaches like grammar translation method (Cook 2001 a). At the end of the nineteenth century, an opposing voice towards using L1 in the foreign language classroom was aired by the Direct Method and Reform Movement in a radical form, both advocating a focus on the exclusive use of $L 2$ in the classes. This argument was later presented frequently by those supporting the use of the exclusive use of L2, maintaining the acquisition hypothesis of L1=L2 (Dulay \& Burt, 1974).

In the same vein, in the behavioristic era,1920s, the focus was on 'speech habits' and 'habit formation' which were against using L1(Laviosa, 2014)because, as practiced by some methods like audiolingual approach, use of L1 was considered an interference in L2 learning process causing bad habits. However, the studies of error analysis in 1960s indicated that only one third of the mistakes taking place in the class were due to learners' L1.With the shift from the behavioristic paradigm to a cognitive one, the use of L1 was not regarded as an interfering source any more but seen as an intervening source in the development of foreign or second language learners' interlanguage. Meanwhile, with the advent of the humanistic paradigm, some methods and approaches advocated using L1 in the EFL classrooms; such as Community Language Learning, the New Current Method, Silent Way, and Dodson's Bilingual Method' and Suggestopedia (Cook, 2001b). It was believed that learning involves feelings and when the learners are not in the safe atmosphere and are under threat, resistance to learning is likely to occur (Stober, 2006). Use of L2 was regarded as a main source of threat and anxiety; thus, L1 could be used to minimize anxiety and enhance the personal security (Brown, 2007).

With the theories defining communicative competence and approaches such as Communicative Language Teaching, the use of L1 could be applied as a strategy within language learners' strategic competence to maintain the communication. Code switching, switching between two or more languages, occurred frequently in the communications between language learners or language learners and their teacher sharing the same L1. One reason that children in the classrooms use their L1 is the lack of L2 background and this absence makes students unable to think in L2 (Macaro, 2005). According to Piaget, students can learn something better, if they have a background knowledge about that issue; therefore, in this context, the background knowledge of learners are their native language, thus L1 can be a positive meditator in L2 learning, not an interfering factor mentioned before. The use of this communication strategy aimed to make conversation easier and more appropriate regarding the linguistic and cultural contexts influencing the classroom atmosphere(Macaro, 2005). Code switching also happened in the second language classroom between students with the same first language. (Macaro, 1997) found that some language learners felt frustrated and could not understand the input that their teachers provided in the L2; thus, they tried to know the exact meaning of the utterances by code switching into their L1. Furthermore, Nichols \& Colon(2000) reported that code switching between L1 and L2 by both teachers and learners in the second language classrooms could facilitate the process of second language learning

Language teachers have a lot of reasons for using L1 in the class. Some of these reasons are building personal 
relationship with learners, giving complex procedural instructions for carrying out an activity, controlling pupils' behavior; translating and checking learners' understanding in order to speed things up due to the time pressures, and teaching grammar explicitly (Macaro, 2000). Using L1 by second language teachers can be used in planning and pre-writing stages of L2 in writing tasks (Lally, 2000).

Brooks-Lewis, (2009) reported language learners' positive attitudes towards the incorporation of L1 in the learning and teaching of foreign language. A classroom-based research study was conducted with university students in English as a foreign language course incorporating the L1. At the end of the course, the participants in the study expressed their perception concerning the use of L1 in their experience. They regarded the incorporation of $L 1$ as a benefit to their experience of learning the foreign language. However, some children' parents, mainly carrying the legacies of the behavioristic paradigm, might still cast their doubts against the use of L1 in the class and try to send their children to the countries where English is the native language of people so that their children sit in the classrooms where they cannot find any person with the same first language (Macaro, 2005). Another reason that parents send their children abroad is the access to non-native teachers. They believe that their children cannot expand their language abilities at home because in some cases teachers themselves do code switching.

Most of the studies focusing on the use of L1 have applied quantitative surveys, providing little contextualized information about the use of L1 in the classroom; however, the complexity of the use of L1 can be explored in light of the genesis underlying the thoughts, experiences, and attitudes of teachers, learners, and their parents via Vygotsky's genotypic approach (1981). Vygotsky proposed that the language development can be evaluated from the perspective of four interrelated levels in interaction with children's environments and introduced 4 domains in which a genetic approach is required in order to provide an adequate account of human mental processes and these are as follows: microgenetic, ontogenetic, phylogenetic, and sociohistorical. Ontogenetic development refers to development of the individuals over their lifetime. Microgenetic development refers to changes that occur over relatively brief periods of time, such as the changes that one may see in a child solving addition problems every week for 11 consecutive weeks(Siegler \& Jenkins, 1989).Phylogenetic development refers to changes over evolutionary time, measured in thousands and even millions of years. Sociohistorical development refers to the changes that have occurred in one's culture and the values, norms, and technologies such a history has generated. This four interrelated domains is the more recent work in the Vygotskian tradition, but the greatest emphasis has been on the ontogenetic and sociohistorical developments influence on the microgenetic analysis of development. English language teachers' attitudes towards the use of L1 in the class on one hand, ontogenetic development, and the policies and regulations of the institutes regarding the use of L1 by the language teachers and learners on the other hand, socio-historical span, can have direct influence of the conditions of the use of L1 in the foreign or second language learning in the classroom, micro analysis.

With the spread of English language around the world and its current state as an international language and the world lingua franca, the exploration of the local context of learning English language is more needed than before. Within the context of Iran, the use of Persian language in the classes of learning English seems very controversial. On one hand, it seems that the regulations for the use of L1 in the English language institutes limits both learners and teachers in this regard; on the other hand, children's parents, representing the demands of the society on both the English language institutes and teachers, play a pivotal role on the constructions of Persian use in the classroom. Thus, the present study aims to explore the determining factors on the use of Persian language in the English language classrooms from a genotypic approach via the following questions:

1. What are the teachers', learners' and parents' attitude towards using Persian in the English language learning classes

2. What are the effects of using the learners' Persian in the class?

3. Does Using Persian in the class have facilitative or debilitative role in English language learning classes?

\section{Method}

\subsection{Participants}

A sample of 33 male and 7 female primary school level students studying English with their age ranging from 9 to 12 and their parents participated in this study. 4 parents were not willing to participate in the study. Also 30 female English language teachers with their age ranging from 21 to 33, with their educational level from B.A. to Ph.D., participated in this study based on convenience sampling in Mashhad, a city in North East of Iran. 


\subsection{Interview}

An unstructured interview with teachers, learners and their parents were conducted within a period of six months to compare and analyze their views and beliefs towards using or not using Persian in the EFL classroom. The interview was applied as a method due to the ecological nature of the research in this study. In ecological research, relationship between organisms and their physical environment is explored. Since the interaction between learner and the environment is crucial to the controversy of use of L1 in English language classes, this study utilized the Vygotsky's genotypic approach. Thus, learners, parents, teachers and institution policies can have a great impact on use of L1, which rightly justifies an ecological approach in which a language classroom can be considered as an eco-system that the above mentioned elements are interacting with each other; therefore, an unstructured interview was conducted with teachers, learners and parents in English language institutes. This type of interview was used to make interviewees flexible to refer to the different aspects of the use of Persian language which might be unpredictable for the researchers. Furthermore, case studies of the challenges on the use of Persian over English language assignments between parents and their children were video recorded.

\subsection{Data Collection}

Interviews with teachers, learners and their parents were conducted in a relaxed atmosphere so that the interviewees could reveal their experiences, opinions, beliefs, and feelings regarding the use of Persian language in the classes. During the process of the interviews, especially with the children, the interviewer, one of the researchers in this study, tried to be a sympathetic listener providing the interviewees with small facial gestures such as attentive lean, a sympathetic smile, and the eyebrow flash. In the interviews with children and parents, they were given appropriate reinforcement feedback from time to time so that they would feel that their comments were worthwhile and praised because most of them reported that they were interviewed for the first time and had a little stress. Besides, they were encouraged for elaboration with appropriate attention focusing devices where necessary. In addition, some of the interviews with the children were video recorded because they were willing to point to the activities in their text books in which they were supposed to use Persian but where banned by their teachers in the classroom. Each interview took from 20 to 30 minutes. All the recorded interviews were transcribed. Afterwards, they were categorized into different codes based on the different aspects of the use of Persian in the classroom.

\section{Results}

The following codes were extracted from the interviews and they were classified from the most frequent to the least frequent.

1. Use of $\mathrm{L} 1$ to understand $\mathrm{L} 2$

2. Use of $L 1$ to prevent fossilization

3. Use of $L 1$ to familiarize learners with the situations of the $L 2$ learning

4. Sense of mediation

5. Sense of security

6. Means of Progress

7. Time saving

8. Sense of building rapport

Exemplification and explanation of each method are as follows:

\subsection{Code 1-(Use L1 to understand L2)}

Some examples for this cod are:

- Using L1 to understand the abstract and difficult concepts.

- Using L1 to understand L2 better.

- Using L1 for removing ambiguities.

- Using L1 for clarifying complicated structures and vocabularies.

- Using L1 for learning materials easily.

Table 1 shows the frequency of code 1 (Use L1 to understand L2) among teachers, learners and parents. 
Table 1 - The frequency of using code 1 (Use L1 to understand L2)

\begin{tabular}{|l|c|c|c|}
\hline Code 1. Use Persian to understand English & Teachers & Learners & Parents \\
\hline Frequency & 10 & 33 & 7 \\
\hline
\end{tabular}

As seen in Table 1, the high majority of learners, about half of the parents and one third of teachers agreed on speaking Persian for better understanding English in the EFL classrooms. An 8 year old learner said:

"I like my English teacher to speak Persian in our classroom because sometimes I cannot understand what is happening in the classroom. I sometimes feel I am like a statue that cannot understand anything in the classroom."

Another 9 year old student said:

"Sometimes, when my teacher uses too much English language in the classroom, I cannot understand her and I become confused .For this reason, I like my teacher to speak Persian in some situations."

Also, one of the parents who with a 9 year child said:

"If my son's teacher only speaks in English, students cannot get 100\% of their teachers' speech because some children like my son are very sensitive to their teachers and also it is useful if English teachers explain the unknown words in Persian which might be very difficult for children to understand."

In addition, one of the teachers, who was 22 years old and was a junior student in teaching English as a foreign language said:

"We as teachers are not supposed to speak Persian in our classrooms, but sometimes we do have to. But, I believe in speaking Persian in English classes, as our professors at university say, students cannot completely comprehend the instructions in the class, if we only speak in English. So, sometimes it seems necessary to speak Persian in our classrooms in order to make the lessons much more tangible for our learners, but we have to consider this point that speaking Persian in our classroom should be in a controlled way and based on the needs of the situation."

Another teacher mentioned:

"In some situations such as presenting grammatical points or some abstract ideas that learners, especially at the beginning level, have problems understanding using Persian seems very useful for explanation \& clarification purposes."

\subsection{Code 2 (Use of $L 1$ to prevent fossilization)}

Some examples for this code:

- Using only L2 to manage learners' language

- Using only L2 to prevent the false learning of the structures in English

Table 2 illustrates the frequency of code 2 (Use of $L 1$ to prevent fossilization) among teachers, learners and parents.

Table 2 - The frequency of code 2 (Use of L1 to prevent fossilization)

\begin{tabular}{|l|c|c|c|}
\hline Use of L1 to Prevent Fossilization & Teachers & Parents & Learners \\
\hline Frequency & 8 & 3 & 0 \\
\hline
\end{tabular}

As seen in Table 2, 12 teachers and 11 parents referred to this code. However, no learner referred to this code in the interviews. Some teachers thought that their learners' speech might be fossilized because they, sometimes under the pressure of speaking in English use structures which they might not still master and this way they internalize false structures. Thus, speaking in Persian can interfere in the process of fossilization in the learners' language.

One of the teachers, 25 years old and wit 4 years experience in teaching English to children said:

Sometimes when I'm speaking English in my class, I feel that my learners use the structures I have taught them in a 
wrong way, so in situations like these I have to speak in Persian in order to restructure what they have learnt and help them to use them accurately.

A parent, with an 8 year old child, who was proficient enough in English said:

"Sometimes English language teachers only speak in English and they expect my daughter to speak in English at this level. I occasionally see that she does not use the structures well. I feel worried that these wrong structures remain forever."

\subsection{Code 3 (Use of $L 1$ to familiarize learners with the situations of the $L 2$ learning)}

Some examples for this code are as follows:

- Using L1 to remind learners of the familiar situations they have experienced in their L1 and now they are supposed to experience in $\mathrm{L} 2$.

- $\quad$ Using L1 to manage the common experiences between L1 and L2.

Table 3 shows the frequency of code 3 (use of L1 to familiarize learners with the situations of the L2 learning) among teachers, parents and learners.

Table 3 - The frequency of code 3 (Use of L1 to familiarize learners with the situations of the L2 learning)

\begin{tabular}{|l|c|c|c|}
\hline Code 3 & Teachers & Parents & Learners \\
\hline Frequency & 18 & 9 & 0 \\
\hline
\end{tabular}

As seen in Table 3, 18English language teachers believed that using Persian in the classroom can help learners to better understand the situations and environments similar to those in L1 acquisition. This way they feel that some of their experiences of learning English are like those in Persian. Some parents also maintained that using Persian by teachers can reduce the stress caused by entering the next environment of the English classroom. Again no learners mentioned this point. One parent, 35 years old with BA degree in Persian Literature, with a 10 year old son said:

In my opinion, when a child enters the English language class with unfamiliar environment, unfamiliar teachers, and unfamiliar language, they might feel confused. So considering this situation, the teachers should run the class partially in Persian to prepare learners for the situations which might be familiar for them like their names, last names, family members and nationality.

One of the teachers, 27 years old and five years of teaching experience said:

Some parents bring their children to English language institutes very soon and they might not be mentally ready for example when they are 4 or 5 years old. So they cannot adapt themselves to the new context of the classroom. Using Persian, teachers can cater to the needs of learners to feel relaxed and well prepared for learning English.

\subsection{Code 4 (Sense of Mediation)}

Some examples for this code are as follows:

- Using L1 to understand the key words.

- Using L1 to transfer the information easily and quickly.

- Using L1 to eliminate any ambiguity.

Table 4 shows the frequency of code 2 (Sense of mediation) among teachers, parents and learners.

Table 4 - The frequency of code 4 (Sense of mediation)

\begin{tabular}{|l|c|c|c|}
\hline Sense of mediation & Teachers & Parents & Learners \\
\hline Frequency & 17 & 8 & 0 \\
\hline
\end{tabular}

As seen in Table 4, 8parents and 17teachers look at using Persian in the EFL classrooms as a meditative tool. According to the teachers, there are some points whose children have difficulty understanding; thus, the use of Persian can play the role of a mediator facilitating the process of understanding and consequently leading to better understanding and language learning. Also, they considered using Persian in the EFL classes as a tool for scaffolding learners' language 
learning. To them, L1 can be used when needed for the purpose of clarifying the presented materials to the learners. A teacher, 25 years old and M.A. in teaching English as a foreign language with four years of teaching English experience to children said:

"In our classroom, we can simply speak Persian in order to explain tasks which seem difficult for the learners causing major difficulty in their performance. In these situations, we speak Persian as a mediator in order to manage their performance and eliminate their ambiguities."

One of the parents with a 10 year old child said:

"I think it is good to speak Farsi at some special occasions; teachers should look at it as a tool in order to help our children understand English better. Sometimes, I want to help my daughter with her assignments at home but since her teacher had taught the instructions in English, she did not know how to do the activities and I could not help her either."

\subsection{Code 5 (Sense of security)}

- Some examples for this code are as follows:

- Using L1 to provide a relaxing atmosphere in the class.

- Using L1 for removing students' worries and uncertainties.

- Using L1 for encouraging students.

- Using L1 for engaging them in the task

- Motivating learners to in the process of learning $L 2$.

Table 5 shows the frequency of code 5 (Sense of security) among teachers, parents and learners.

Table 5 - The frequency of code 5 (Sense of security)

\begin{tabular}{|l|c|c|c|}
\hline Sense of Security & Teachers & Parents & Learners \\
\hline Frequency & 19 & 11 & 21 \\
\hline
\end{tabular}

As seen in table 5, most of the teachers asserted that Persian can be used as a suitable tool for improving the learners' sense of security in English classes while a few of parents did as well. Besides, 21 learners reported that they need to feel relaxed and secure in the class. Most of them maintained that exclusive use of English in the class cause so much emotional pressure, anxiety, and stress for them in the classroom and when their teachers speak in Persian they feel comfortable in the classroom.

A 27 year old teacher, M.A. in English language teaching and has 5 years teaching experience to children said:

"For several times, I have seen that my learners feel stressed in the class especially in the first sessions. So it is necessary to speak Persian in these critical moments to provide them with a peaceful atmosphere in the class. Children are so sensitive to the situation they are in and they can easily abandon their classes and feel anxious and lose their motivation if they do not feel relaxed and emotionally prepared."

One of the parents with an 8 year old child said:

"I remember when first I enrolled my son in an English language institutes, he was a bit stressed and the context of the institute, the supervisor, and the teacher introducing herself with an English accent added to his level of stress. He came back home and asked me not to take him there again because he did not like his class. His father and I had arguments over this issue because I wanted my child to learn English like the other children and this seemed embarrassing for me, as a mother, that I could not persuade my son into going to the English class. But the next day his teacher helped him by speaking in Persian at the beginning of the class which seemed really effective in creating a mentally safe place for my son."

\subsection{Code 6 (means of progress)}

Some examples for this code are as follows:

- Using L1 as a scaffolding tool

- Using L1 to have promotion in basic levels. 
- $\quad$ Using $L 1$ to pave the way learning $L 2$.

Table 6 shows the frequency of code 6 (Sense of promotion) among teachers, parents and learners.

Table 6 - The frequency of code 6 (means of progress)

\begin{tabular}{|l|c|c|c|}
\hline Means of Progress & Teachers & Parents & Learners \\
\hline Frequency & 11 & 4 & 9 \\
\hline
\end{tabular}

Table 6 shows that 11 teachers, 4 parents and 9 learners believed in speaking Persian as a tool for promoting learners' language learning in the classroom. In this case, L1is used as an aid for learners to improve their L2; they are more likely to move to higher levels sooner. Since language learners, especially children, are at the early stages of language learning, they are in need of taking advantage of using their L1, Persian, to set the stage for the next levels. One of the students, 10 years old said:

"l like my English teacher to speak Persian because we are still in the first level, because we want to learn English very fast, so if our teacher speaks in Persian we can underhand English quickly and get prepared for the exams better."

One teacher, 26 years old with 6 years of experience in teaching to children said:

"Sometimes in some specific situations, it is better to speak in Persian especially in basic levels, because I think exclusive use of English in the classroom, as I have experienced, might hinder students for moving forward. They are in need of progress in learning English, English Language institutes expect us to speak English almost all the time with the children, but I have seen that this might be to the detriment of the beginner learners' understanding."

Another teacher, Ph.D. candidate in teaching English as a foreign language and 12 years of teaching experience said:

'Exclusive use of English in the class not only reduces learners' motivation but also might prevent them from their progress in learning English. Imagine that you are learning a language like Italian or German with no background in these languages. You are sitting in a class with all the input in these languages. How do you feel? Does it motivate you to follow learning these languages?"

One of the parents with a 12 year old daughter said:

"Three years ago, when my daughter registered for an English language class, I expected her teacher to speak in English all the time because it was very important for me to see my daughter's progress very soon, but after three times I found her really unwilling to participate in her English class. When I asked the reason, she said that she had not understood her teachers' language. She has stopped learning English for two years and I was worried that she might not continue learning English anymore. But now fortunately she has just started again and I asked her teacher to speak in Persian so that she can be more willing to move forward."

\subsection{Code 7 (time saving)}

Some examples for this code:

- Using L1 to save time for explaining difficult contents.

- Using L1 to accelerate explanation and classification.

Table 7 shows the frequency of code 8(time saving) among teachers, parents and learners.

Table 7 - The frequency of code 7 (time saving)

\begin{tabular}{|l|c|c|c|}
\hline Time saving & Teachers & Parents & Learners \\
\hline Frequency & 18 & 7 & 4 \\
\hline
\end{tabular}

As seen in table 7, 18 teachers and 7 parents, 4 learners asserted that Persian can be used in the class to save time. Teachers mainly believed that in teaching complicated and abstract words, there is no need for too much repetition or circumlocution. Besides, they maintained that excessive use of $\mathrm{L} 2$ in situations like this is really time-consuming, because 
students cannot understand all the explanations in the L2. So, the only way for saving the class time is to use Persian when needed. In almost all levels of language learning, there are situations that learners might have problems understanding the main points of the presented materials; as a result, they might need more explanation and clarification which might take the class time if answered in English. Besides, this process can be frustrating for students. Therefore, teachers can use Persian for saving and managing the class time.

A 35 year old teacher, M.A. in teaching English as a Foreign Language and 9 years of teaching experience said:

"Sometimes, we, as teachers, might be asked by our learners to explain the meaning of some unknown words. Following the regulations of the institutes, we are supposed to explain them in English but it will be really timeconsuming because some the words might be abstract ones or beyond their level of understanding. Explaining them in Persian can save time in my opinion."

Another 27 year old teacher said:

"In some of my classes that I don't have enough time for explaining grammatical points, I prefer using L1 rather than spending too much time because my experiences have shown that finally I have to explain them in Persian so that everyone can understand."

One parent with a 12 year old child said:

"I have observed that sometimes teachers do not have enough time especially when the session is going to be over and they have to finish their lessons soon. This way, my child's mind might be occupied with so much information in a short period of time. I think that by using Persian in this case, they can manage their time well."

Likewise, one of the learners, 11 years old said:

"Sometimes my classmates ask the teachers the meaning of the words they do not know, so teachers try to answer them in English, and I see that my classmates, despite the efforts of teachers, still do not know the answer and other students feel bored. Then, the students who know the meaning whisper in Persian the meaning of the words to them and they understand. I think teachers can do this in these moments."

\subsection{Code 8 (Sense of building rapport)}

Some examples for this code:

- Using L1 to provide a friendly atmosphere between teachers and learners

Table 8 shows the frequency of code 8 (Sense of building rapport) among teachers, parents and learners.

Table 8 - The frequency of code 8 (Sense of building rapport)

\begin{tabular}{|l|c|c|c|}
\hline Building rapport & Teachers & Parents & Learners \\
\hline Frequency & 14 & 4 & 8 \\
\hline
\end{tabular}

As seen in table 8, 14 teachers, 14 parents, and 8 learners highlighted the role of using Persian in class for the construction of a friendly atmosphere. Teachers mainly asserted that when working with elementary learners, children or adults, using Persian can shorten the distance between learners and teachers. Similarly, learners maintained that teachers' exclusive use of English keeps the distance between learners and teachers.

One of the students, 8 years old said:

"I like my English teacher, but I couldn't understand her, because he always speaks in English and I cannot make rapport with her, because she never speaks in Persian... and if she speaks in Persian I can understand her and I can make a good relationship with her."

One of the parents with a 10 year old child said:

"I think English teachers can make a good relationship with children through ...speaking Persian with them because this is their mother tongue and by hearing their mother tongue they fell relaxed." 
One of the learners, 12 years old said:

"I remember when in the first session of the class I faced my teacher, she started speaking English with me. I liked the way but felt really stressed. The next time when I had questions I did not dare to ask because I felt embarrassed of making mistakes. I looked a ther like an alien. But once she spoke in Persian, I could breathe a sigh of relief and feel that she is someone like us. So I was not afraid of asking questions in the class anymore."

Beside the above codes some learners and parents pointed that if the teacher speaks in Persian, it will stop their language learning.

Some examples of this case:

- $\quad$ By Using L1, students do not try to learn more L2.

- Using L1 can postpone learning L2.

The following table shows the frequency of parents and learners toward this attitude. (Stop learning L2)

Table 9 - The frequency of parents, teachers and learners' attitudes towards the use of $L 1$ which stops learning $L 2$

\begin{tabular}{|l|c|c|c|}
\hline The attitude & Parents & Learners & Teachers \\
\hline Frequency & 16 & 3 & 7 \\
\hline
\end{tabular}

Table 9 shows that half of the interviewed parents maintained that the use of Persian and in the class can have debilitative effect on their children's progress in learning English. Besides, seven teachers, five of them B.A. in teaching English as Foreign Language maintained so.

One of the learners, 9 years old said:

"I don't like my English teacher speak Persian in our classroom, because we are in English class, and we want to learn English language not Persian."

Likewise, another learner, 11 years old, said:

"I like my English teacher only speak in English, because when she is speaking English, I can remember the words I have learnt so that's why she doesn't need to speak in Persian....may be in the early days, it seems difficult for us, but we gradually used to hear only English in English classes."

One of the parents, having an 8 year old child said:

"My daughter is 8 years old, her teacher only speaks in English and this lets her learn more words besides her course books."

In a similar vein, another teacher said:

"Never speak in Farsi in English classes. Because when a teacher only speaks in English, students can understand and learn new words better especially the usage of each word. So when children are in this situation, they have to listen very carefully in order to understand what the teacher is telling them."

\section{Discussion}

The participants' interviews regarding the advantages of using Persian in the class can discussed from different perspectives. First of all, using Persian can used a means for better understating the input of the English language. It can be interpreted that Children learn new things based on their background knowledge and it happens when there is a balance and harmonious relationship (equilibrium) between their cognitive structures, and from a Piagetian perspective this balance stars with the process of assimilation (Isaacs, 2015). That is, they learn the new materials, which is English, by internalizing them into their existing schema, which has been configured by Persian(Shaffer, 2009). Since children have already constructed their reality via their experiences using Persian, thus the construction of the new reality via the use of English language takes place in light of their mother tongue which is Persian. Ignoring their prior experiences in the process of learning the new language, English, might keep them in a state of disequilibrium, where they might experience insecurity, and losing their motivation. 
In addition, the meditative role of Persian in the English language classes can be interpreted from the learners' zone of proximal development (ZPD). Vygotsky coined the term ZPD referring to the distance between the actual and potential ability of individuals (Chaiklin, 2003). This distance can be filled with the role of mediator (Shaffer, 2009). The role of language as a mediator in the development of childhood cognition should not be ignored(Moore, 2013). Thus, Persian can mediate the process of English language learning for Iranian elementary learners. As seen in the interviews, there were cases where learners had problems understanding the instructions presented to them by their teachers and this affected their performance in the class activities. Using Persian as a mediator in the class not only does not hinder their progress but also boosts their potentials in terms of understanding what they are supposed to do with the activities in the class so that they can perform them well.

Also, even if teachers do not use Persian in the class, learners take advantage of their background thoughts which is in Persian, acquired through their inner speech. They might talk to themselves, not to be noticed by their teachers, in Persian while listening to their teachers' instructions or doing the activities in the class. That is, it is a kind of evidence that learners use in order to regulate their learning in English, L2, by their thoughts in Persian, L1(Lantolf \& Appel, 1994).Therefore, when students understand something by using $L 1$, they appropriate the necessary concepts derived from their L1, Persian, to manage their own performance in the similar occasions in learning English.

On the other hand, one argument in favor of teachers' the exclusive use of L2 is related to Krashen's input hypothesis that all learners with different levels of competence are all able to comprehend the teaching content successfully (Krashen \& Terrell, 1983); thus, teachers can explain everything in L2 and reasonably exclude L1 use from EFL classrooms. However, it is noticeable to say that L2 input is without doubt necessary, but it seems not enough for the input to become intake and needs other mediating factors, like learners' attention, the perceptual saliency of the items, and learners' prior linguistic and encyclopedic knowledge, which are mainly in Persian(Gass, 1997). One of the problems that students may face in their learning of new language is that they may learn it in the wrong form because the instruction they receive is all in $\mathrm{L} 2$, and they may learn them in the wrong ways, as observed in the interviews. Thus, if these controlled processes become automatic prematurely, before they are well formed, they will become fossilized (McLaughlin 2013).According to McLaughlin (2013), L1 can be used as a tool for preventing fossilization in SLA. The teacher can use L1 for the purpose of clarification of preventing the error items become fixed in the learners' long term memory

Besides, as the interviews indicated, the use of Persian in the class can be justified from a humanistic perspective. Macaro (1997) found that some learners feel frustrated and cannot understand the input the teacher provides in the L2 and in fact they need to know the exact meaning of the utterances for better L2 learning. According to Maslow's hierarchy of needs, in order to help learners to trust the teacher and the new environment, they need to understand what is happening around them. So considering the elementary level of language learners, it seems that one of helping learners understand the situation and make it safe and secure for them is using the learners' native language (L1). In this way they can understand the environment, trust the teacher and as a result feel secure in the class situation. In addition, in Maslow's hierarch of needs, one level belongs to safety needs playing a pivotal role in students' learning. Based on this factor, for better language learning, learners first need to feel secure and relaxed enough in the class situation in order to understand the presented materials. To accomplish this goal for the elementary level English language learners using Persian, learners' L1, can be influential because it can reduce anxiety among students and make them feel relaxed and ready to learn the new information, as reported in the interviews.

Regarding the advantage of using Persian for saving time, As Macaro (2000) reported, one of the main reasons teachers use L1 is for translating and checking learners' understanding or in another word, monitoring them, in order to speed things up due to the limitations of time they may face in their classrooms. Likewise, the International Teacher Training Organization recently reported that incorporating L1 in classes can be time-saving by 'translating a word or two', but cautioned teachers to in using a student's L1 because this reliance on L1 might be very difficult to lose in the process of the students' progress (ITTO 2007).

The majority of parents asserted that using Persian can have a debilitative role in the process of learning the English language. In fact, they think that the acquisition of L2 is the same as the L1 (Dulay \& Burt, 1974)but we should consider that these situations might work for acquiring some linguistic features and structures and we cannot address them to every aspects of language learning.

Finally, the reports of the interviews can be interpreted in light of Vygotsky's genotypic approach. A look at the tables of the frequency of the codes for the use of Persian in the classroom indicates that the majority of parents' opinions regarding the use of Persian are in contrary with the teachers' opinions. On the other hand, as the educational level of the English language teachers interviewed increases, more constructive attitudes towards the use of Persian in the class are observed. Besides, most of the teachers in their interviews referred to the tough regulations of the English language 
institutes in Iran preventing them from using Persian in the class. Thus, the ontogenetic development of Iranian English language teachers, represented in their educations level, seems to be in contrast with the sociohistorical span represented in the beliefs of English language learners' parents, mainly children's, and the policies of English language institutes. And these contrasts affect the microgeny, which is the classroom behavior. Parents seem to be influenced by the beliefs of regarding a similar process for both L1 and L2 acquisition and the English language institutes follow the beliefs rooted in the behavioristic traditions of not using Persian in the class to avoid any cases of interference between the two languages.

\section{Conclusion}

Regarding the main principles of post-method pedagogy, the particularity of the context of teaching influences the practicality of the classroom. One of the controversial issues within the particular context of Iran is the use of Persian in the class. Thus, the present study aimed to explore the pedagogical influences of the use of Persian, from an emic perspective, based on the beliefs and attitudes of Iranian English language teachers, learners, and their parents. The findings of the study indicate that teachers have lots of reasons to use L1 in their classes supported by some new theories and approaches within the field of applied linguistics. On the other hand, they are forbidden to use Persian mainly due to the sociohistorical and the norms of the institutes that they are working for. Therefore, it is concluded that teachers are in a big dilemma; that is, they are ontogenetically become aware of being allowed to use L1, but the social norms reflected in the policies of the English language institutes and the beliefs of parents representing the social patterns dominant in the society overshadow their ontogenetic awareness. Thus, their classroom behaviors in terms of using Persian in the class can be under the influence of the intertwined influence of sociohistorical patterns and ontogenetic changes.

\section{References}

Basavadatta, M., \& Amit, R. (2011). Multilingualism: Mother Tongues as the Tool for Learning in Classrooms. Paper presented at the International Professional Communication Conference (IPCC), 2011 IEEE, Cincinnati, OH, USA.

Brooks-Lewis, K. A. (2009). Adult learners' perceptions of the incorporation of their L1 in foreign language teaching and learning. Applied Linguistics, 30(2), 216-235

Brown, H. D. (2007). Principles of Language Learning and Teaching (5th ed.). United States of America: Pearson Longman.

Chaiklin, S. (2003). The zone of proximal development in Vygotsky's analysis of learning and instruction. Vygotsky's educational theory in cultural context, 1, 39-64.

Cook, V. (2001a). Using the first language in the classroom. Canadian Modern Language Review/La Revue canadienne des langues vivantes, 57(3), 402-423.

Cook, V. (2001b). Using the first language in the classroom. Canadian Modern Language Review, 57(3), 402-423.

Dulay, H. C., \& Burt, M. K. (1974). Errors and strategies in child second language acquisition. TESOL QUARTERLY, 129-136.

Gass, S. M. (1997). Input, Intraction, and the Second Language Learner (Second Language Acquisition Research: Theoretical 7 Methodological Issues). Hillsdale: Lawrence Erlbaum.

Hancock, M. (1997). Behind Classroom Code Switching: Layering and Language Choice in L2 Learner Interaction. Tesol Quarterly, 31(2), 217-235. doi: $10.2307 / 3588045$

International Teacher Training Organization. 2007. 'Using L1 in the TEFL classroom,' available at http://www.teflcertificatecourses. com/tefl-articles/L1-teflclassroom. html. Accessed 16 December 2008.

Isaacs, N. (2015). A brief introduction to Piaget. Algora Publishing.

Krashen, S. D., \& Terrell, T. D. (1983). the Natural Approach: Language Acquisition in the Classroom: Pergamon Press.

Lally, C. (2000). First Language influence in Second Language Composition: the Effect of Pre-writing. Foreign Language Annals, 33(4), 428-432. doi: 10.1111/j.1944-9720.2000.tb00623.x

Lantolf, J. P., \& Appel, G. (1994). Vygotskian Approaches to Second Language Reasearch: Greenwood Publishing Group.

Laviosa, S. (2014). Translation and Language Education: Pedagogic Approaches Explored: Routledge.

Macaro, E. (1997). Target Language Collaborative Learning and Autonomy (pp. 231). Celevedon: Multilingual Matters.

Macaro, E. (2000). Issue in Target Language Teaching. In K. Field (Ed.), Issues in Modern Foreign Languages Teaching (pp. 171-189). London: Routledge.

Macaro, E. (2005). Codeswitching in the L2 Classroom: A Communication and Learning Strategy. Non-Native Language Teachers, 5, 63-84.

McLaughlin, B. (2013). Second language acquisition in childhood: Volume 2: School-age Children.PsychologyPress

Moore, P. J. (2013). An Emergent Perspective on the Use of the First Language in the English-as-a-Foreign-Language Classroom. the Modern Language Jornal, 97(1), 239-253.

Nichols, P., \& Colon, M. (2000). Spanish Literacy and the Academic Success of Latino High School Students: Codeswitching as a 
Classroom Resource. Foreign Language Annals, 33(5), 498-511. doi: 10.1111/j.1944-9720.2000.tb01994.

Shaffer, D. (2009). Developmental Psychology: Childhood and Adolescence (8th ed.): Wadseorth Publishing.

Siegler, R. S., \& Jenkins, E. (1989). How Children Discover New Strategies. Hillsdale, NJ: Lawrence Erlbaum Associates.

Stober, D. R. (2006). Coaching from the humanistic perspective. Evidence based coaching handbook, 17-51.

Turnbull, M. (2001). There is a Role for the L1 in Second and Foreign Language Teaching, But.... Canadian Modern Language Review/ La Revue canadienne des langues vivantes, 57(4), 531-540. doi: 10.3138/cmlr.57.4.531

Vygotsky, L. S. (1981). The genesis of higher mental functions. The concept of activity in Soviet psychology, 144-188. 